Journal of Agrometeorology 23 (2) : 169-175 (June 2021)

\title{
Evaluation of linear and nonlinear models for temperature driven development of Spodoptera litura (Fabricius) on soybean crop
}

\author{
Y.G. PRASAD ${ }^{*}$, M. GAYATHRI ${ }^{1}$, V. SAILAJA ${ }^{2}$, M. PRABHAKAR ${ }^{1}$, G.RAMACHANDRA RAO ${ }^{1}$, \\ G. REKHA ${ }^{1}$ and S. VENNILA ${ }^{3}$ \\ ICAR-Central Institute for Cotton Research (CICR), Nagpur \\ ${ }^{I}$ ICAR-Central Research Institute for Dryland Agriculture, Hyderabad \\ ${ }^{2}$ Forest College and Research Institute, Osmania University, Mulugu \\ ${ }^{3}$ ICAR-National Research Centre for Integrated Pest Management, New Delhi \\ *Corresponding author:ygprasad@gmail.com
}

\begin{abstract}
The tobacco caterpillar, Spodoptera litura, a major pest of soybean in India is under surveillance in all soybean growing areas in Maharashtra in order to issue alerts to farmers and prevent economic losses. In this context, two linear models were fitted to developmental data of $S$. litura life stages reared on soybean at five constant temperatures viz. $15,20,25,30$ and $35^{\circ} \mathrm{C}$ through laboratory experiments. Optimum temperature for development $\left(T_{\text {opt }}\right)$ and upper temperature threshold $\left(T_{\text {max }}\right)$ were estimated from three nonlinear models by additionally including developmental response at $>35^{\circ} \mathrm{C}$. $T_{\text {opt }}$ estimates for the total immature development were $34.5^{\circ} \mathrm{C}$ (Lactin-2), $33.7^{\circ} \mathrm{C}$ (Briere-1) and $33.2^{\circ} \mathrm{C}$ (Simplified Beta type function) while $\mathrm{T}_{\max }$ estimates were in the range of 38 to $40^{\circ} \mathrm{C}$. Application of a thermodynamic non-linear model (Optim SSI) gave estimate ofintrinsic optimum temperature $\left(\mathrm{T}_{\varphi}\right)$ for development of egg $\left(28.3^{\circ} \mathrm{C}\right)$, larva $\left(27.5^{\circ} \mathrm{C}\right)$ and pupal stage $\left(30.3^{\circ} \mathrm{C}\right)$. The phenology model of $\mathrm{S}$. litura on soybean based on estimated developmental threshold temperatures and thermal constants was validated using available field surveillance data to facilitate informed pest management decisions.
\end{abstract}

Key words: Spodoptera litura, threshold temperatures, degree days, phenology model

Spodoptera litura (Lepidoptera: Noctuidae) is an economically important pest on several crops and incidence of the pest often crosses economic threshold level on several field crops including soybean. Outbreak of S. litura on soybean has become a challenge for its management on soybean in India (Prasad et al., 2013).Temperature is a key factor for driving insect development (Pedigo 1989). Most studies on the developmental biology of S. lituraon several hosts analyzed linear response to constant temperatures in the range of 15 to $40^{\circ} \mathrm{C}$ (Ranga Rao et al., 1989; Qin et al., 2002; Manimanjari et al., 2014; Srinivasa Rao et al., 2014). The estimates of bioclimatic thresholds and constants are useful in phenology modelling and comparative analysis of different geographical populations. Phenology model of $S$. litura was validated with surveillance data from several locations in soybean growing areas to test its utility in predicting the timing of seasonal occurrence. Field application of the model makes it possible to issue pest alert advisories to soybean farmers for informed pest management decisions.

\section{MATERIALS AND METHODS}

\section{Development studies at constant temperatures}

Laboratory experiments were conducted using environmental growth chambers (MLR $350 \mathrm{H}$ and $351 \mathrm{H}$, Sanyo, Japan). The insect culture was maintained on soybean foliage (most popular cultivar JS335) at $60 \pm 5 \%$ relative humidity and photoperiod (14:10 L:D). Virgin pairs of adults were released on potted soybean plants for oviposition. Freshly laid 5 egg masses (between 250 to 500 eggs) were individually placed in Petri dishes ( $9 \mathrm{~cm}$ diameter) and were observed for hatching at constant temperatures at an increment of $5^{\circ} \mathrm{Ci}$.e., $15,20,25,30$ and $35^{\circ} \mathrm{C}$ in separate experiments. Neonate larvae (0-12 h old) from each cohort of hatched egg mass were individually transferred on to fresh soybean foliage in Petri dishes and observed daily. Pupae were transferred to individual glass tubes to observe adult emergence. Each temperature treatment was repeated with another 25 larvae (5 larvae/ replication, 5 replications/temperature).In order to elicit non-linear development of S. litura life stages beyond $35^{\circ} \mathrm{C}$, similar constant temperature experiments were 
Table 1: Mathematical models used to describe the relationship between temperature and development rate for $S$. litura

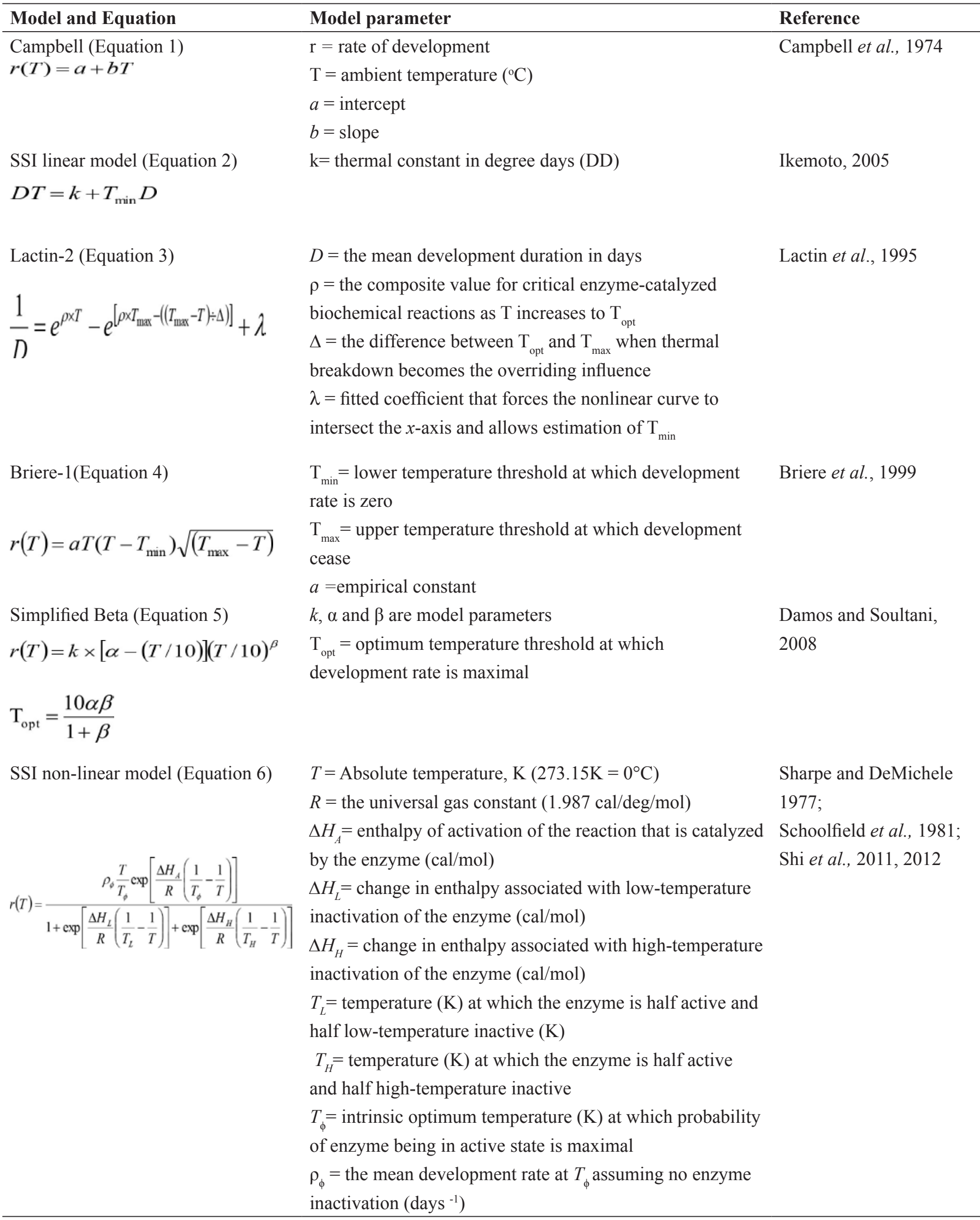


performed between 36 to $40^{\circ} \mathrm{C}$ at one-degree increment. The pooled sample sizes of survivors that completed immature development from egg to adult emergence analyzed were as follows: 28 survivors at $15^{\circ} \mathrm{C}, 42$ at $20^{\circ} \mathrm{C}, 38$ at $25^{\circ} \mathrm{C}, 41$ at $30^{\circ} \mathrm{C}, 37$ at $35^{\circ} \mathrm{C}$ and 33 at $36^{\circ} \mathrm{C}$.

\section{Bioclimatic threshold and thermal constants}

Development duration (days) of instars was converted to development rate (1/days) at each temperature. Linear and non-linear models were fitted to describe the rate of development of $S$. litura as a function of temperature to estimate bioclimatic development thresholds and thermal constants.

\section{Statistical analyses}

Linear regression was performed with mean developmental rate data using PROC REG to determine linear relationship between rate of developmental $(1 / D)$ and temperature $(\mathrm{T})$ using equation 1 (Table 1) to obtain regression parameters $(a$ and $b)$.

\section{Validation of degree-day model}

Accumulated degree-days (ADDs) were calculated and compared between observed and predicted incidence of S. litura on soybean. Input start date was the observed first field incidence (bio-fix date) and accumulation till larval peak incidence in the rainy season of 2016 (June to October) from several field locations in four soybean growing districts in Maharashtra as part of the Crop Pest Surveillance and Advisory Project (CROPSAP) (http://mahaagriiqc.gov. in/cropsapadm/index.php). Estimated degree-days for completion of egg, larva and pupal stages were taken from our study while the estimate for pre-oviposition period (29 DD) was taken from Ranga Rao et al. (1989). Accumulated degree-days for one generation (larva to larva, 489 DD) from an observed start date were calculated using the degree day calculator from UCIPM website (http://ipm.ucanr.edu/ WEATHER/index.html) opting for single sine horizontal cut-off method and providing threshold temperatures $\left(\mathrm{T}_{\text {min }}\right.$ and $\mathrm{T}_{\max }$ ) as input values. Daily weather data (minimum and maximum temperatures) for different locations were sourced from nearest meteorological observatory for calculating ADD. Paired t-test was performed to compare predicted and observed ADDs for larval stage (bio-fix date to peak incidence). Timing of next generation egg stage (442 DD) was also aimed at to have forecast value in pest management advisories.

\section{RESULTS AND DISCUSSION}

Temperature markedly influenced development of life stages of S. litura on soybean (Fig 1). Developmental durations of egg, larva, pupa and total immature decreased linearly as temperature increased in the range of 20 to $35^{\circ} \mathrm{C}$. Beyond $35^{\circ} \mathrm{C}$, complete development from egg to adult emergence was observed only at $36^{\circ} \mathrm{C}$ but showed non-linear response for all life stages. Regression of developmental rate data in the linear temperature range $\left(20-35^{\circ} \mathrm{C}\right)$ gave the estimates of lower developmental threshold temperature $\left(\mathrm{T}_{\text {min }}\right)$ and thermal constant $(\mathrm{k})$ for all the life stages and total immature development (Table 2). The estimated lower developmental threshold temperature $\left(\mathrm{T}_{\min }\right)$ for egg, larva, pupa and total immature life span of $S$. litura were 11.3, 11.7, 11.5 and $12.1^{\circ} \mathrm{C}$ with Campbell model, and 10.5, 11.2, 11.1 and $11.9^{\circ} \mathrm{C}$ with SSI linear model, respectively (Table 2). Similarly, thermal constants (k) were $46.9,271.7,141.0$ and 448.4 DDs with Campbell model and 50.5, 284.7, 144.4 and 458.2 DDs with SSI linear model, respectively. Upper temperature threshold $\left(\mathrm{T}_{\max }\right)$ estimates for life stages and total immature development obtained from Lactin-2, Briere-1 and Simplified beta type function were between 38.0 and $40.1^{\circ} \mathrm{C}$. The estimated optimum temperature threshold $\left(\mathrm{T}_{\mathrm{opt}}\right)$ for the total immature development was 34.5, 33.7 and 33.2 from Lactin-2, Briere-1 and Simplified Beta type function, respectively.

Nonlinear thermodynamic SSI model gave estimates of intrinsic optimum temperature $\left(\mathrm{T}_{\varphi}\right)$, which were $28.3^{\circ} \mathrm{C}$ for development of egg, $27.5^{\circ} \mathrm{C}$ for larva and $30.3^{\circ} \mathrm{C}$ for pupa. The estimated upper threshold temperatures $\left(\mathrm{T}_{\mathrm{H}}\right)$ with SSI model were between 35.8 and $36.3^{\circ} \mathrm{C}$ for all life stages (Table 3).

\section{Development at constant temperatures}

Development of S. litura life stages were studied at constant temperatures on different host plants by several researchers. Studies on peanut (Ranga Rao et al., 1989; Srinivasa Rao et al., 2014), sunflower (Manimanjari et al., 2014) and cabbage (Qin et al., 2002) addressed the developmental response of life stages at temperatures in the linear range only. In this paper, development of $S$. litura was attempted at higher temperatures $\left(>35^{\circ} \mathrm{C}\right)$ and complete development was observed till $36^{\circ} \mathrm{C}$, which showed a nonlinear response. We included developmental data of only surviving individuals that completed full immature development from egg to adult emergence in both linear and nonlinear modes. In 
Table 2: Model parameter estimates for development of $S$. litura life stages*Description of parameters in Table 1

\begin{tabular}{llllll}
\hline Model & Parameters* & Egg & Larva & Pupa & Total immature \\
\hline Campbell & $\mathrm{T}_{\min }$ & $11.3 \pm 1.26$ & $11.7 \pm 1.71$ & $11.5 \pm 0.57$ & $12.1 \pm 2.43$ \\
& $\mathrm{~K}$ & $46.9 \pm 4.32$ & $271.7 \pm 34.94$ & $141.0 \pm 5.03$ & $448.4 \pm 70.97$ \\
\multirow{2}{*}{ Linear SSI } & $\mathrm{R}^{2}$ & 0.9752 & 0.9196 & 0.9975 & 0.9522 \\
& $\mathrm{~T}_{\min }$ & 10.5 & 11.2 & 11.1 & 11.9 \\
& $\mathrm{~K}$ & 50.5 & 284.7 & 144.4 & 458.2 \\
Lactin-2 & $\mathrm{R}^{2}$ & 0.9920 & 0.9555 & 0.9996 & 0.9918 \\
& $\mathrm{~T}_{\text {opt }}$ & 34.5 & 35.6 & 35.9 & 34.5 \\
& $\mathrm{~T}_{\max }$ & 40.0 & 40.0 & 40.0 & 38.0 \\
Briere-1 & $\mathrm{R}^{2}$ & 0.9651 & 0.9512 & 0.9983 & 0.9546 \\
& $\mathrm{~T}_{\text {opt }}$ & 33.4 & 33.5 & 33.8 & 33.7 \\
& $\mathrm{~T}_{\max }$ & 40.0 & 40.0 & 40.0 & 40.0 \\
Simplified beta type & $\mathrm{R}^{2}$ & 0.9446 & 0.9112 & 0.9691 & 0.9153 \\
function & $\mathrm{T}_{\text {opt }}$ & 33.0 & 33.3 & 33.4 & 33.2 \\
& $\mathrm{~T}_{\max }$ & 40.0 & 40.1 & 40.1 & 40.0 \\
\hline
\end{tabular}

Table 3: Parameter estimates of non-linear thermodynamic SSI model for S.litura life stages

\begin{tabular}{llll}
\hline Parameter* & Egg & Larva & Pupa \\
\hline $\mathrm{T}_{\varphi}\left({ }^{\circ} \mathrm{C}\right)$ & 28.3 & 27.5 & 30.3 \\
$\mathrm{~T}_{\mathrm{L}}\left({ }^{\circ} \mathrm{C}\right)$ & 4.1 & 13.4 & 14.9 \\
$\mathrm{~T}_{\mathrm{H}}\left({ }^{\circ} \mathrm{C}\right)$ & 36.3 & 36.3 & 35.8 \\
$\boldsymbol{X}^{2}$ & 0.00535 & 0.00397 & 0.00004 \\
$\mathrm{R}^{2}$ & 0.9920 & 0.9555 & 0.9996 \\
\hline
\end{tabular}

* Description of parameters in Table 1

other studies, nonlinear response was observed at still higher temperatures of $37^{\circ} \mathrm{C}$ on peanut (Ranga Rao et al., 1989). However, it is possible that these differences could be due to differences in experimental conditions.

Bioclimatic thresholds $\left(T_{\min }, T_{o p t}, T_{\max }\right.$ and $\left.T_{\varphi}\right)$

In our study, Campbell model using developmental rates in the linear range of 20 to $35^{\circ} \mathrm{C}$ gave $\mathrm{T}_{\text {min }}$ estimates between 11.3 and $11.7^{\circ} \mathrm{C}$ for all life stages. SSI linear model returned lower $\mathrm{T}_{\text {min }}$ values with better model fit statistics $\left(\mathrm{R}^{2}\right)$ (Table 2). However, Campbell model was selected as it returned comparable estimates of lower threshold temperature for initiation of development across life stages and also gave standard error estimates for number of degreedays required for completion of each life stage. The estimated degree-days from linear SSI model were within the standard error ranges of thermal constants for life stages estimated from the Campbell model and corroborated the thermal summation used in validation of the phenology model. Lower temperature threshold and thermal constants for development from constant temperature experiments are widely estimated using the simple linear model of Campbell (Padmavathi et al., 2013). Linear fit to developmental rate data of $S$. litura has been reported on peanut (Ranga Rao et al., 1989; Srinivasa Rao et al., 2014).

Three empirical models assessed the nonlinear relationship of development rate with temperature to estimate theoretical optimum temperature $\left(\mathrm{T}_{\text {opt }}\right)$ and upper threshold temperature $\left(\mathrm{T}_{\max }\right)$. Theoretical estimates of $\mathrm{T}_{\max }$ were similarly estimated by all three models at $40^{\circ} \mathrm{C}$. However, best fit model estimates of $\mathrm{T}_{\text {opt }}$ for all life stages and total immature life span were obtained with Lactin-2 model based on higher coefficient of determination $\left(\mathrm{R}^{2}\right)$ (Table 2 ). $\mathrm{T}_{\text {opt }}$ values were closest to the observed fastest development rate at $35^{\circ} \mathrm{C}$. Hence, Lactin- 2 is preferred over the other two nonlinear models for giving biologically relevant estimates. Increased developmental time of $S$. litura life stages at $36^{\circ} \mathrm{C}$ 
Table 4: Field validation of S. litura phenology model in crop season (June to October) during 2016 in Maharashtra

\begin{tabular}{|c|c|c|c|c|c|c|c|c|}
\hline \multirow[t]{2}{*}{ District } & \multirow[t]{2}{*}{$\begin{array}{l}\text { No. of } \\
\text { locations }\end{array}$} & \multirow{2}{*}{$\begin{array}{l}\text { Biofix (date } \\
\text { of first } \\
\text { incidence) }\end{array}$} & \multicolumn{2}{|c|}{$\begin{array}{c}\text { Expected larval peak } \\
\text { incidence }\end{array}$} & \multicolumn{2}{|c|}{$\begin{array}{c}\text { Observed larval peak } \\
\text { incidence }\end{array}$} & \multicolumn{2}{|c|}{$\begin{array}{l}\text { Expected egg mass } \\
\text { incidence }\end{array}$} \\
\hline & & & Date & $\begin{array}{l}\text { Accumulated } \\
\text { degree-days }\end{array}$ & Date & $\begin{array}{l}\text { Accumulated } \\
\text { degree-days }\end{array}$ & Date & $\begin{array}{r}\text { Accumulated } \\
\text { degree-days }\end{array}$ \\
\hline Amravati & 32 & $9 \mathrm{Aug}$ & $14 \mathrm{Sep}$ & 494.1 & 15 Sep & 506.4 & $11 \mathrm{Sep}$ & 454.2 \\
\hline Washim & 70 & 9 Aug & 11 Sep & 498.2 & 9 Sep & 468.6 & $07 \mathrm{Sep}$ & 440.5 \\
\hline Parbhani & 30 & 29 Aug & $30 \mathrm{Sep}$ & 484.9 & $30 \mathrm{Sep}$ & 484.9 & $28 \mathrm{Sep}$ & 453.3 \\
\hline Akola & 11 & 15 Aug & $13 \mathrm{Sep}$ & 489.0 & $15 \mathrm{Sep}$ & 521.6 & $11 \mathrm{Sep}$ & 455.4 \\
\hline
\end{tabular}
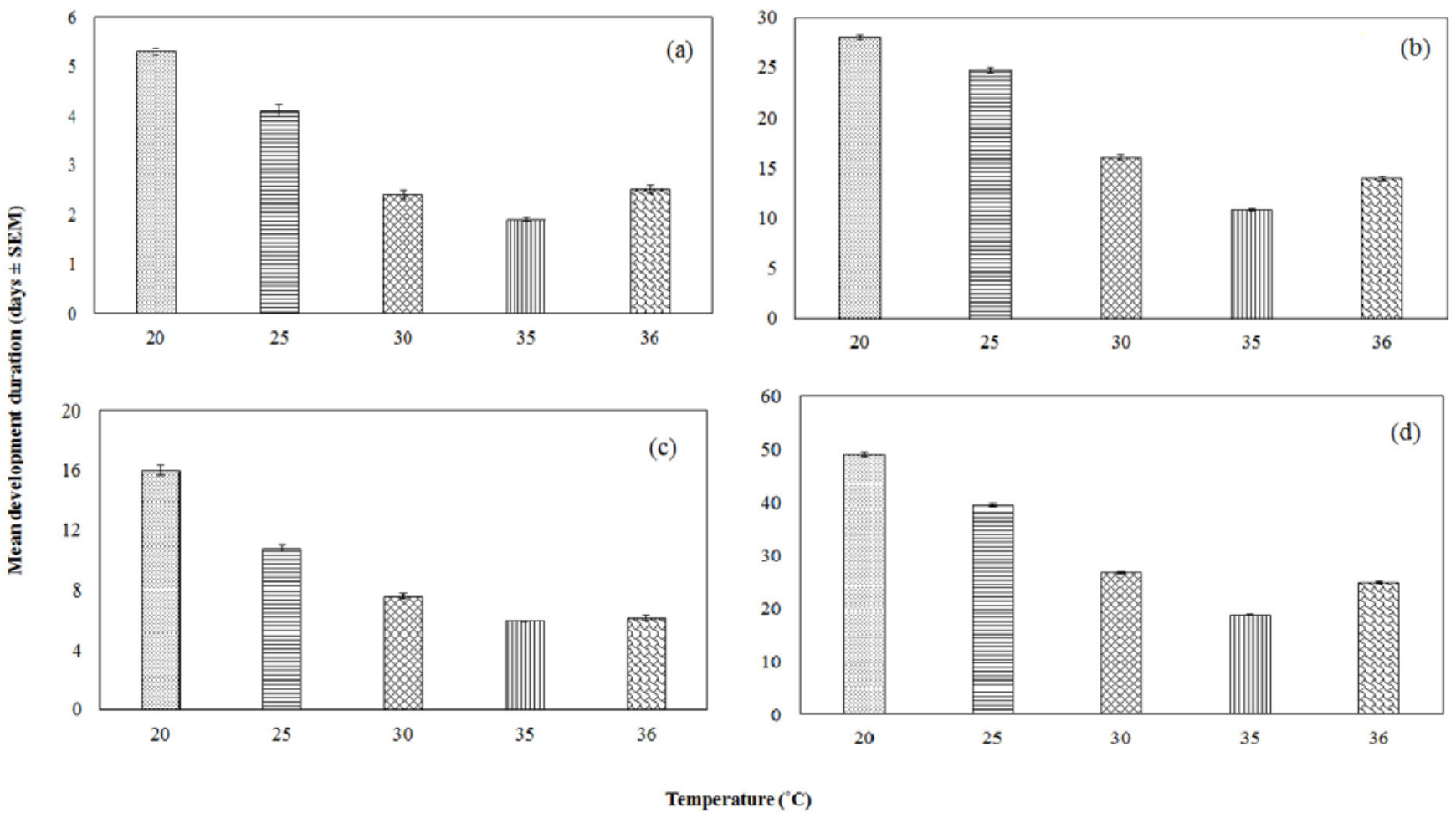

Fig 1: Temperature dependent development of S. litura life stages: (a) egg, (b) larva, (c) pupa, and (d) total immature life span

is probably explained by the best-fit estimates of $\mathrm{T}_{\mathrm{H}}$ from the thermodynamic nonlinear SSI model. $\mathrm{T}_{\mathrm{H}}$ is the temperature at which enzymes related to development are half-active and half-high temperature inactive (Shi et al., 2011) and probably explain the observed slower development rate. Values of $\mathrm{T}_{\mathrm{H}}$ were lower than the upper lethal $\mathrm{T}_{\max }$, the temperature above which development ceases. Intrinsic optimum temperature $\left(\mathrm{T}_{\varphi}\right)$ estimated from thermodynamic SSI model indicated most favourable temperatures for maximal enzyme activity related to development of egg, larval and pupal stages of S. litura and also indicated the adaptation of a species to its thermal environment (Shi et al., 2012). Evaluation of linear and non-linear models explained the developmental responses (initiation, peak, decline and cessation) of $S$. litura life stages to a range of temperatures.

\section{Field validation of phenology model}

Validation of degree-day model was attempted for S. litura by comparing timing of predicted and observed phenological events using actual field pest surveillance data on soybean, which was employed previously in case of other pests (Blomefield and Gilimoee, 2014). Pest surveillance on soybean is implemented by State Department of Agriculture, Government of Maharashtra every season to provide pest alerts to farmers for timely pest management. First incidence of S. litura was observed between 9 and 29 August, 2016 at 143 locations spread across four soybean growing districts in Maharashtra. Pest scout data from weekly sampled fields (fixed fields over time) indicated peak larval incidence above the economic threshold level (ETL, $>4$ larvae/ $\mathrm{m}$ crop row at post flowering stage) (Vennila et al., 2016) between 9 and 
30 September, 2016. Observed timing of larval incidence in next generation was not significantly different from predicted time of larval occurrence based on accumulated degree-days calculated from bio-fix dates in August $(\mathrm{t}=0.294, \mathrm{df}=3, \mathrm{P}=$ 0.788) (Table 4). Predicted timing of egg stage was 2 to 4 days prior when compared to the observed incidence of damaging larval stage across locations. Forecasts of egg stage of S. litura can assist more frequent surveillance at crucial times to provide pest alerts and prepare for management interventions (Javaid, 1990).

\section{CONCLUSION}

Bioclimatic parameter estimates from this study were useful in predicting the timing of S. litura on soybean in area-wide pest surveillance and issue of pest management advisories. Evaluation of both linear and nonlinear models and comparison of parameter estimates with other $S$. litura populations reported on other hosts was helpful in arriving at more precise estimates necessary for practical field application. Intrinsic optimum temperature threshold estimates from thermodynamic modelling for S. litura populations was not previously reported, which appears to be an important indicator of population development coinciding with peak crop damage when daily average temperatures approximate the threshold. However, temperature despite being a key driver of insect development, there are several other factors such as rainfall, humidity and regulation by natural enemies which are important as well in insect population dynamics under field conditions. Validation of phenology model with field surveillance data is one step forward in this direction. Development as a function of temperature reported in this study along with inputs from modelling of survival and growth of $S$. litura can be utilized in the development of more comprehensive simulation models for predicting potential geographical distribution, timing and abundance as reported for other pests. The results of this study can thus be applied in practice for informed decision making in pest surveillance projects currently being implemented on soybean in India.

\section{ACKNOWLEDGEMENT}

Optim SSI package in R-software was kindly provided by Dr Peijian Shi. Sharing of field data from CROPSAP project in Maharashtra is duly acknowledged.

\section{REFERENCES}

Blomefield, T.L., Gilimoee, J.H. (2014). Validation of the phenology model for the codling moth, Cydiapomonella
(Lepidoptera:Tortricidae), in South African pome fruit orchards. African Entomol, 22: 30-48.

Briere, J.F., Pracros, P., Le Roux, A.Y., Pierre, J.S. (1999). A novel rate model of temperature-dependent development for arthropods. Environ Entomol., 28: 22-29.

Campbell, A., Frazer, B.D., Gilbert, N., Gutierrez, A.P., Mackauer, M. (1974). Temperature requirements of some aphids and their parasites. J Appl Ecol., 11: 431438 .

Damos, P.T., Savopoulou-Soultani, M.S. (2008). Temperature-dependent bionomics and modeling of Anarsia lineatella (Lepidoptera: Gelechiidae) in the laboratory. J Econ Entomol., 101, 1557-1567.

Javaid, I., 1990. Application of insecticides in Zambia: Timing of spray application. Int. J. Pest. Manag., 36 (1): $1-9$.

Lactin, D.J., Holliday, N.J., Johnson, D.L., Craigen, R. (1995). Improved rate model of temperature-dependent development by arthropods. Environ. Entomol., 24: 6875.

Ma, J., Hu, X.N., Peng, Z.Q., Liu, H.J., Liang, F. (2011). The potential geographical distribution of Phenacoccus solenopsis Tinsley based on the CLIMEX in China. Plants Quarantine 25: 5-8.

Manimanjari, D., Srinivasa Rao, M., Swathi, P., Rama Rao, C.A., Vanaja, M., Maheswari, M. (2014). Temperature and $\mathrm{CO}_{2}$-dependent life table parameters of Spodopteralitura (Noctuidae: Lepidoptera) on sunflower and prediction of pest scenarios. J. Insect Sci 14: 297. doi: 10.1093/jisesa/ieu159

Padmavathi, C., Katti, G., Sailaja, V., Padmakumari, A.P., Jhansilakshmi, V., Prabhakar, M., Prasad, Y.G. (2013). Temperature thresholds and thermal requirements for the development of the rice leaf folder, Cnaphalocrocismedinalis. J. Insect Sci., 13, 96

Pedigo, L.P. (1989). Entomology and Pest Management. Macmillan Publishing Company.

Prasad, Y.G., Gayathri, M., Prabhakar, M., Jeyakumar, T., Vennila, S., Subba Rao, A.V.M., Bhaskara Rao, I., Rao, K.V., Ramachandra Rao, G., Rao, V.U.M. (2013). Population dynamics of Spodoptera litura outbreak on soybean vis-a-vis rainfall events. J Agrometeorol., 15 (Special Issue-I): 37-40. 
Qin, H.G., Ye, Z.X., Ding, J., Huang, S.J., Luo, R.H. (2002). Effect of temperature on the development, survival and fecundity of Spodopteralitura Fabricius.[J]. Chin. J. Eco Agric., 10 (3):76-79.

Ranga Rao, G.V., Wightman, J.A., Ranga Rao, D.V. (1989). Threshold temperatures and thermal requirements for the development of Spodoptera litura (Lepidoptera: Noctuidae). Environ Entomol., 18(4): 548-551.

SAS Institute (2009). Proc user's Manual, version 9.2 ed. Cary, NC: SAS Institute.

Schoolfield, R.M., Sharpe, P.J., Magnuson, C.E. (1981). Nonlinear regression of biological temperature-dependent rate models based on absolute reaction-rate theory. $J$. Theor. Biol., 88(4): 19-731.

Sharpe, P.J.H., DeMichele, D.W. (1977). Reaction kinetics of poikilotherm development. J. Theor. Biol., 64: 649-670.

Shi, P., Ikemoto, T., Egami, C., Sun, Y., Ge, F. (2011). A modified program for estimating the parameters of the SSI model. Environ Entomol., 40: 462-469.

Shi, P., Li, B.L., Ge, F. (2012). Intrinsic optimum temperature of the diamondback moth and its ecological meaning. Environ Entomol., 41: 714-722.

Srinivasa Rao, M., Manimanjari, D., Rama Rao, C.A., Swathi, P., Maheswari, M. (2014). Effect of climate change on Spodoptera litura Fab. on peanut: a life table approach. Crop Prot., 66: 98-106.

Vennila, S., Lokare, R., Singh, N., Ghadge, S.M., Chattopadhyay, C. (2016). Crop pest surveillance and advisory project of Maharashtra - A role model for an e-pest surveillance and area wide implementation of integrated pest management in India. ICAR National Research Centre for Integrated Pest Management, New Delhi 110 012, India. 56p. 